\title{
Facile Synthesis of Nanosized Magnesium-Aluminium Layered Double Hydroxides
}

\author{
Kedar Nath Dhakal ${ }^{1,2}$, Girja Mani Aryal ${ }^{1,2}$, Hari Sharan Adhikari ${ }^{1,2,3}$, Rameshwar Adhikari*1,2 \\ ${ }^{1}$ Central Department of Chemistry, Tribhuvan University, Kirtipur, Kathmandu, Nepal \\ ${ }^{2}$ Research Centre for Applied Science and Technology (RECAST), Tribhuvan University, Kathmandu, Nepal \\ ${ }^{3}$ Department of Applied Sciences, Institute of Engineering, Western Region Campus, Tribhuvan University, \\ Pokhara, Nepal \\ *Corresponding E-mail: nepalpolymer@yahoo.com
}

(Received: March 30, 2020; Revised: January 4, 2021; \& Accepted: January 4, 2021)

\begin{abstract}
We report facile methods of preparing nanosized hydrotalcite-like compounds, the layered double hydroxides (LDH), with ordinary chemistry laboratory settings to educate the young scientists from high schools to undergraduate university level fostering their research interest in preparing these nanomaterials of practical importance. Coprecipitation and urea hydrolysis methods have been recommended as facile routes of preparing the magnesium-aluminum layered double hydroxides $(\mathrm{Mg}-\mathrm{Al} \mathrm{LDH})$. The LDH thus prepared were characterized by Fourier transform infrared (FTIR) spectroscopic and powder X-ray diffraction (XRD) techniques. The observed weakening of some FTIR peaks and XRD planes shifting concerning standard JCPDS 89-5434 data implied the slight structural variation of the compounds and the presence of some impurities. The average grain diameter of LDH particles was found in the range of 20 to $60 \mathrm{~nm}$.
\end{abstract}

Keywords: Hydrotalcite, layered double hydroxides (LDH), FTIR spectroscopy, X-ray diffraction

\section{Introduction}

Layered double hydroxides (LDH) are 2-dimensional, hydrotalcite $\quad\left[\mathrm{Mg}_{6} \mathrm{Al}_{2}(\mathrm{OH})_{16} \mathrm{CO}_{3} \cdot 4 \mathrm{H}_{2} \mathrm{O}\right]$-like basic inorganic compounds. They are represented by the general formula.

$$
\left[\mathrm{M}^{2+}{ }_{(1-x)} \mathrm{M}^{3+}{ }_{\mathrm{x}}(\mathrm{OH})_{2}\right]^{\mathrm{x+}}\left(\mathrm{A}^{\mathrm{n}-}{ }_{\mathrm{x} / \mathrm{n}}\right) \cdot \mathrm{mH}_{2} \mathrm{O} \text {, }
$$

where,

$$
\mathrm{M}^{2+}=\text { divalent metal cation }
$$

$\mathrm{M}^{3+}=$ trivalent metal cation

$\mathrm{x}=$ an integer $=\mathrm{M}^{3+} /\left(\mathrm{M}^{2+}+\mathrm{M}^{3+}\right)=$ molar fraction $\mathrm{A}^{\mathrm{n}-}=$ organic or inorganic charge compensating anion in inter-lamellar region $\mathrm{m}=$ number of water molecules present per formula weight of compound [1-4].

The general structural scheme of LDH is presented in Figure 1[5].

According to the general formula and the structural scheme shown in Figure 1, these compounds involve positively charged hydroxylated layers $\left[\mathrm{M}^{2+}{ }_{(1-x)}\right.$ $\left.\mathrm{M}^{3+}(\mathrm{OH})_{2}\right]^{\mathrm{x}+}$ separated by interlayered anionic species $\left[\left(\mathrm{A}^{\mathrm{n}-}{ }_{\mathrm{x} / \mathrm{n}}\right) \cdot \mathrm{mH}_{2} \mathrm{O}\right]$ and water molecules $[6,7]$.
Double hydroxides of transition metals of the first row (divalent cations) in periodic table [M(II)] and that of Fe, Al, Cr, Ga, etc. (trivalent cations) [M(III)] compose hydroxylated layers of these compounds.

The tetravalent cations such as $\mathrm{Mn}^{4+}, \mathrm{Sn}^{4+}$ etc. can also be incorporated between the layers [5,6]. $\mathrm{Mg}^{2+}, \mathrm{Zn}^{2+}$, $\mathrm{Co}^{2+}, \mathrm{Ni}^{2+}, \mathrm{Mn}^{2+}$, etc., and $\mathrm{Al}^{3+}, \mathrm{Cr}^{3+}, \mathrm{Fe}^{3+}, \mathrm{V}^{3+}, \mathrm{Co}^{3+}$, etc. are $\mathrm{M}(\mathrm{II})]$ and $[\mathrm{M}(\mathrm{III})]$ cations generally present in basic layers of these compounds. Meanwhile, $\mathrm{CO}_{3}{ }^{2-}$ , $\mathrm{SO}_{4}^{2-}, \mathrm{Cl}^{-}, \mathrm{NO}_{3}^{-}, \mathrm{OH}^{-}$etc. are charge compensating anions present in the interlayer space between two successive layers $[2,3,5,8]$. ' $\mathrm{x}$ ' is the number of moles of M (III) per formula weight of the compound which is equal to the molar fraction i.e. ratio of the molar concentration of $\mathrm{M}$ (II) to the sum of that of M(II) and M(III). It determines the charge density of the hydroxide layers of these compounds. The value of ' $x$ ' lies in the range $0.2 \leq x \leq 0.4$ according to the stoichiometry of the compounds. Ionic radii of M(II) and $\mathrm{M}$ (III) cations, in the range of that of $\mathrm{Mg}^{2+}$ are taken as the best be accommodated in their octahedral sites. On the other hand, too small and too large 

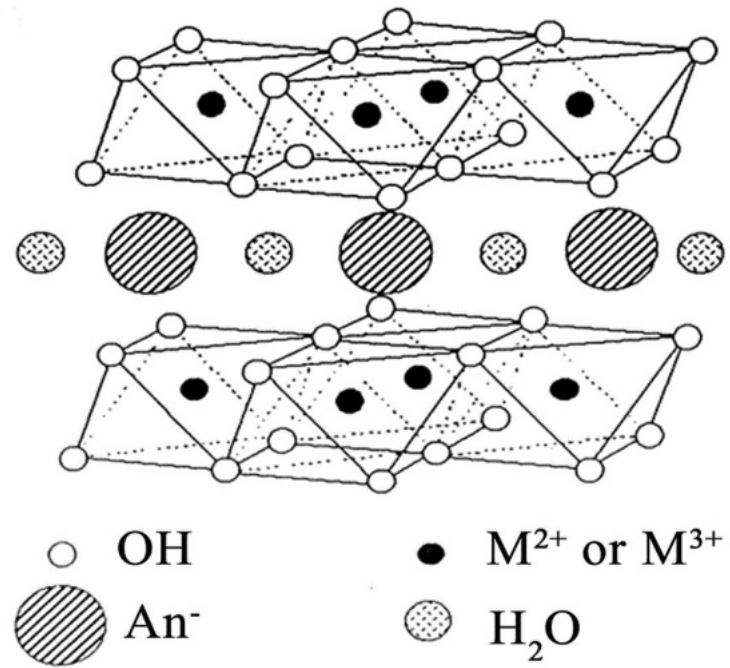

$\mathrm{M}^{2+}=\mathrm{Mg}^{2+}, \mathrm{Ni}^{2+}, \mathrm{Zn}^{2+}, \mathrm{Cu}^{2+}, \mathrm{Mn}^{2+}$,etc.

$\mathrm{M}^{3+}=\mathrm{Al}^{3+}, \mathrm{Fe}^{3+}, \mathrm{Cr}^{3+}$,etc.

$\mathrm{An}^{-}=\mathrm{CO}_{3}{ }^{2-}, \mathrm{SO}_{4}{ }^{2-}, \mathrm{NO}_{3}{ }^{-}, \mathrm{Cl}^{-}, \mathrm{OH}^{-}$, etc.

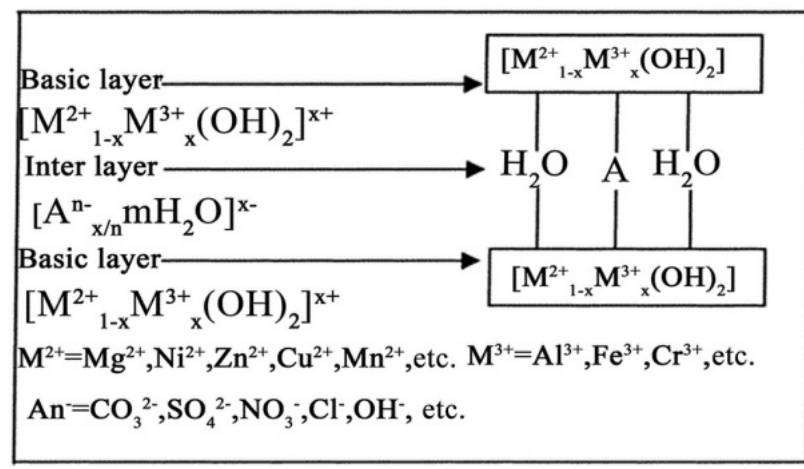

Figure 1: Schematic structure of LDH showing double hydroxide layers (basic layers), metal cations [M(II) and $\mathrm{M}(\mathrm{III})$ ] as layer-species, and anions $\left(\mathrm{A}^{n-}\right)$ and $\mathrm{H}_{2} \mathrm{O}$ as interlayer species [5].

cations such as $\mathrm{Be}^{2+}$ and $\mathrm{Cd}^{2+}$ respectively produce another type of compound instead of LDH $[8,9]$.

The structure of $\mathrm{LDH}$ resembles that of brucite $\left[\mathrm{Mg}(\mathrm{OH})_{2}\right]$ in which $\mathrm{Mg}$ atoms are coordinated with -OH groups in regular octahedral linked to one another through their vertices. The basic hydroxylated layers acquire positive charge because M(II) cations in the lattice are substituted by M(III) cations and the resultant charge is balanced by anions present between these layers. These positively charged layers make them basic [10]. They are porous compounds and exhibit some extraordinary physicochemical properties such as delamination (into positively charged cationic nano-sheets), ion (inorganic and organic) exchange property, extraordinarily high thermal stability, high surface area, and ease of surface modification, etc. These particular properties and unique chemistry make them applicable in various fields in their pristine and modified forms as illustrated in Figure 2 [3,11-15].

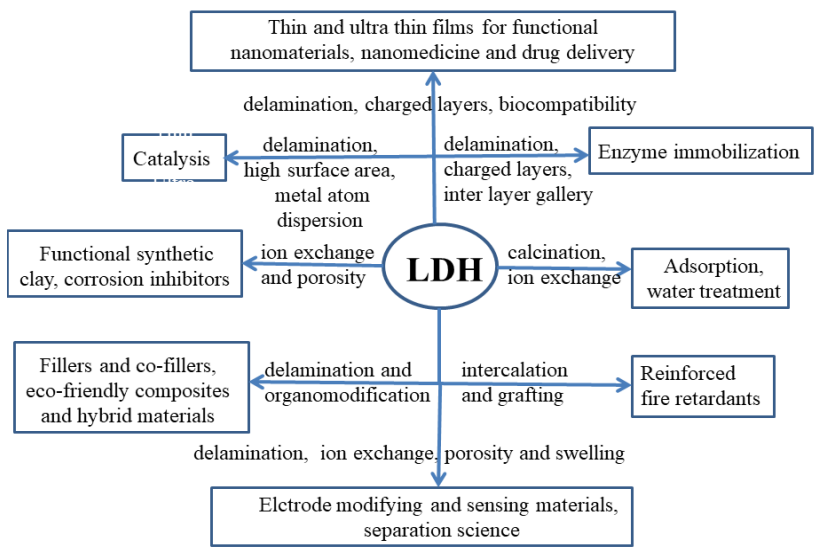

Figure 2: Schematic chart illustrating properties and modifications based applications of LDH (adapted from references $[3,11,13,15-21,24-33]$

To name the most important applications of the LDH, their delaminated nano-sheets are promising materials for sensing [13,18,29,31-33] and catalytic purposes [19], wastewater treatment (such as removal of As(V) and $\mathrm{Cr}(\mathrm{VI})$, phosphates and nitrates) $[15,16,21,26]$, as fire-retardant $[12,24,25,30]$, corrosion inhibitors supercapacitors, as biomaterials, drug delivery hosts, etc. $[7,27,30]$. Based on their porosity and ion exchange property, LDH is emerging as synthetic clay, an alternative to varieties of natural clay [9].

These important materials can be prepared by different wet chemical methods such as coprecipitation, urea hydrolysis, ion exchange, hydrothermal, sol-gel, electro-synthesis, etc. It should be noted that these versatile and yet highly valuable nanomaterials with their unique properties can easily be prepared in an ordinary chemistry laboratory using easily accessible chemicals as starting materials. In this work, we employ coprecipitation and urea hydrolysis methods as facile synthetic routes of preparing nano-LDH.

\section{Materials and Methods}

\section{Materials}

Magnesium nitrate hexahydrate $\left[\mathrm{Mg}\left(\mathrm{NO}_{3}\right)_{2} \cdot 6 \mathrm{H}_{2} \mathrm{O}\right]$, aluminum nitrate nonahydrate $\left[\mathrm{Al}\left(\mathrm{NO}_{3}\right)_{3} \cdot 9 \mathrm{H}_{2} \mathrm{O}\right]$, sodium carbonate $\left(\mathrm{Na}_{2} \mathrm{CO}_{3}\right)$, sodium hydroxide $(\mathrm{NaOH})$, and urea $\left(\mathrm{NH}_{2} \mathrm{CONH}{ }_{2}\right)$ of analytical grade were purchased from Merck Limited, India. Distilled water was used to prepare the corresponding chemical 
solutions. $\left.\mathrm{Mg}\left(\mathrm{NO}_{3}\right)_{2} \cdot 6 \mathrm{H}_{2} \mathrm{O}\right]$ and $\left.\mathrm{Al}\left(\mathrm{NO}_{3}\right)_{3} \cdot 9 \mathrm{H}_{2} \mathrm{O}\right]$ were used as starting materials for the preparation of Mg-Al LDH in both methods.

\section{Preparation of Mg-Al LDH}

Coprecipitation and urea hydrolysis methods adopted in this experiment are presented in Figure 3. $500 \mathrm{~mL}$ mixture salt solution was prepared by mixing 250 $\mathrm{mL}$ of $0.1 \mathrm{M}$ solution of $\mathrm{Mg}\left(\mathrm{NO}_{3}\right)_{2} \cdot 6 \mathrm{H}_{2} \mathrm{O}$ and 250 $\mathrm{mL}$ of $0.05 \mathrm{M}$ solution of $\mathrm{Al}\left(\mathrm{NO}_{3}\right)_{3} .9 \mathrm{H}_{2} \mathrm{O}$. Similarly, $500 \mathrm{~mL}$ of a caustic mixture solution was prepared by mixing $250 \mathrm{~mL}$ of $0.8 \mathrm{M} \mathrm{Na}_{2} \mathrm{CO}_{3}$ solution and 250 $\mathrm{mL}$ of $1.6 \mathrm{M}$ solution of $\mathrm{NaOH}$. The caustic mixture solution was added to $500 \mathrm{~mL}$ mixture salt solutions in a dropwise manner with continuous and vigorous stirring $\mathrm{pH} \sim 9$ of the reaction mixture was maintained because precipitation of all $\mathrm{LDH}$ occurs at a $\mathrm{pH}$ range of 8.5-9.0. As the caustic mixture solution was added to the mixture salt solution, a white precipitate of hydrotalcite was formed and the stirring was continued overnight for complete precipitation. The precipitate was washed with $0.8 \mathrm{M} \mathrm{Na}_{2} \mathrm{CO}_{3}$ solution followed by distilled water until neutrality, filtered, and dried at $80^{\circ} \mathrm{C}$ in an oven overnight to obtain the solid flakes of Mg-Al LDH.

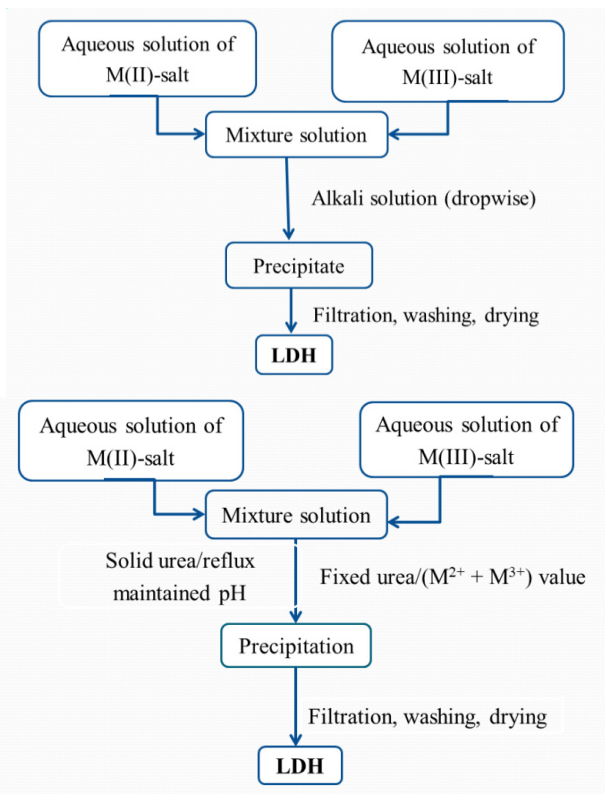

Figure 3: Schemes showing the procedures to prepare nano-LDH by coprecipitation (top) and urea hydrolysis (bottom) methods

Similarly, optimized conditions of molar fraction, temperature, $\mathrm{pH}$ value, and reflux-time as reported in Costantino's method were maintained for the preparation of materials by urea hydrolysis method
[8]. $150 \mathrm{~mL}$ of $0.1 \mathrm{M}\left[\mathrm{Mg}\left(\mathrm{NO}_{3}\right)_{2} \cdot 6 \mathrm{H}_{2} \mathrm{O}\right]$ solution and $150 \mathrm{~mL}$ of $0.05 \mathrm{M}\left[\mathrm{Al}\left(\mathrm{NO}_{3}\right)_{3} .9 \mathrm{H}_{2} \mathrm{O}\right]$ were prepared in such a way that molar fraction $\left(\mathrm{Al}^{3+} / \mathrm{Al}^{3+}+\mathrm{Mg}^{2+}\right)$ value would be 0.33 . These two salt solutions were mixed at a $\mathrm{pH}$ value of $\sim 9$. The solubility of $\mathrm{Mg}(\mathrm{OH})_{2}$ will be higher than that of $\mathrm{Al}(\mathrm{OH})_{3}$ at this $\mathrm{pH}$ value due to which all $\mathrm{Al}^{3+}$ ions will be coprecipitated with $\mathrm{Mg}^{2+}$ maintaining 2:1 stoichiometry of $\mathrm{Mg}$ and Al-ions present in each sheet of LDH. Solid urea was added to the solution mixture with continuous stirring until the molar fraction [urea/ $\left.\left(\mathrm{Al}^{3+} / \mathrm{Al}^{3+}+\mathrm{Mg}^{2+}\right)\right]$ became 3.3. A clear solution was obtained after the dissolution of urea which was refluxed for 36 hours at $100^{\circ} \mathrm{C}$. The white precipitate of LDH obtained was filtered out, washed with distilled water, and dried at $60^{\circ} \mathrm{C}$ in an oven.

\section{Characterization techniques}

Fourier transform infrared (FTIR) spectroscopy FTIR spectra were recorded using SHIMADZU spectrophotometer (IR tracer 100) in the wavenumber range of $400-4000 \mathrm{~cm}^{-1}$.

\section{X-ray diffraction (XRD)}

The crystalline phase and structure of the samples were determined by X-ray diffractometer (Bruker D2 Phaser) with a monochromatic $\mathrm{CuK} \alpha$ radiation source $(\lambda=0.15418 \mathrm{~nm})$ at $2 \theta$ values ranging from $20^{\circ}$ to $80^{\circ}$. The acceleration voltage of $30 \mathrm{kV}$ and emission current of $10 \mathrm{~mA}$ were used.

\section{Results and Discussion}

FTIR spectra of LDH prepared by coprecipitation and urea hydrolysis methods are presented in Figure 4. The peaks that appeared at different wavenumber range in the spectra are due to metal-oxygen bonds, $\mathrm{CO}^{3--}$, $\mathrm{NO}_{3}{ }^{-}$and $\mathrm{OH}^{-}$. However, bands shifting (from actual wave number value) and bands weakening are found to occur. The peaks located below $700 \mathrm{~cm}^{-1}$ (i.e. 454 , 560,698 , and $712 \mathrm{~cm}^{-1}$ ) signify O-M-O and M-O-M vibration and stretching bands of magnesium and aluminum (where $\mathrm{M}=$ Metal) [36,37]. Similarly, the peaks centered at $830,972,1180$ and $2350 \mathrm{~cm}^{-1}$ are due to free $\mathrm{CO}^{3--}$ ions present in the materials which might have been formed by the reaction of atmospheric $\mathrm{CO}_{2}$ during the material synthesis and/or $\mathrm{CO}^{3--}$ derived from $\mathrm{Na}_{2} \mathrm{CO}_{3}$ used $[37,38]$. The prominent band appearing at $1032 \mathrm{~cm}^{-1}$ is because of the stretching vibration of the $\mathrm{C}-\mathrm{O}$ bond present in $\mathrm{CO}_{3}^{--}$ions [38]. Similarly, peaks centered at 1366 and $1508 \mathrm{~cm}^{-1}$ (more intense in the urea hydrolysis method) corresponds to the 
vibrational mode of interlayer $\mathrm{CO}_{3}^{-}$ions as well as $\mathrm{NO}_{3}-[36,38,39]$. Characteristic peaks centered around $1600 \mathrm{~cm}^{-1}$ are due to bending vibration of-OH from interlayer $\mathrm{H}_{2} \mathrm{O}$ molecules [36-38]. Weak and broad bands located between 3000 and $3100 \mathrm{~cm}^{-1}$ are due to the $\mathrm{H}$-bonds formed by the interaction of $\mathrm{CO}_{3}^{--}$ions and water molecules present in interlayer space [37]. Weak bands at $3695 \mathrm{~cm}^{-1}$ correspond to stretching vibration of $-\mathrm{OH}$ derived from metal hydroxides layers, interlayered $\mathrm{H}_{2} \mathrm{O}$ molecules as well as water adsorbed during synthesis $[36,38]$. The spectra of the samples prepared from both synthetic routes resemble each other that confirms the formation of similar materials from both of the methods employed.

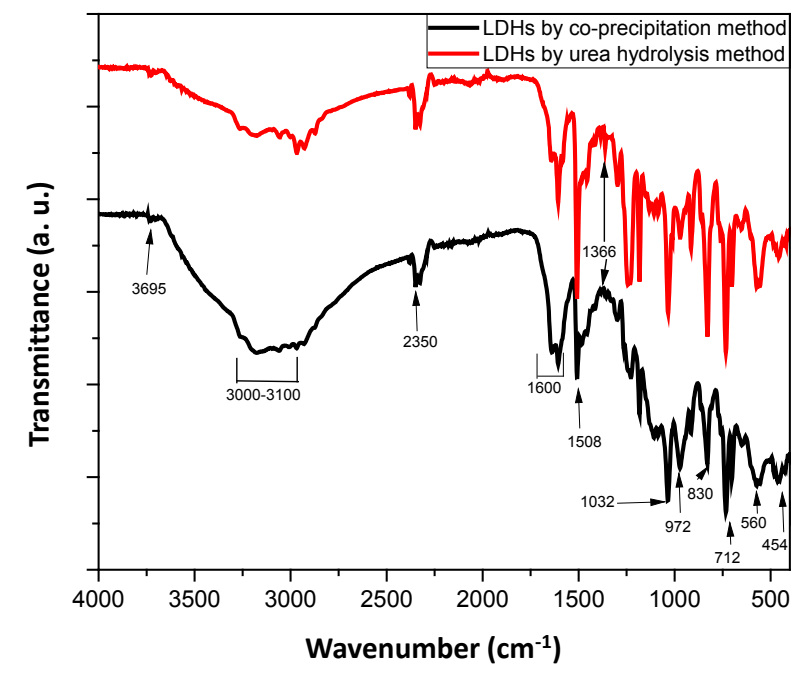

Figure 4: FTIR spectra of LDH prepared by different methods; the spectra are shifted along $Y$ axis for the sake of better comparison

Figure 5 presents the XRD pattern of $\mathrm{Mg}-\mathrm{Al} \mathrm{LDH}$ prepared by the urea hydrolysis method. It shows changes in crystallinity pattern with a little shifting of standard peaks according to JCPDS file number 89$5434[23,35,36]$. Shifting of standard peaks to appear at $2 \theta$ values of $32^{\circ}, 69^{\circ}$ and $72^{\circ}$ to $35^{\circ}, 71^{\circ}$ and $73^{\circ}$ respectively and the appearance of some additional peaks at $29^{\circ}, 40^{\circ}, 56^{\circ}, 61^{\circ}, 62^{\circ}, 67^{\circ}, 71^{\circ}, 73^{\circ}$, and $75^{\circ}$ may be attributed to structural modification along with the adhered impurities of unwashed $\mathrm{CO}_{3}^{--}$and $\mathrm{NO}_{3}^{-}$ions present in the materials, moisture absorbed during storage, etc. [40].

The average particle size of LDH was calculated using the Debye-Scherrer formula given in equation (1).

$$
D=K \lambda / \beta \operatorname{Cos} \theta
$$

where $\mathrm{K}$ is shape factor (0.9), $\lambda$ is the wavelength of

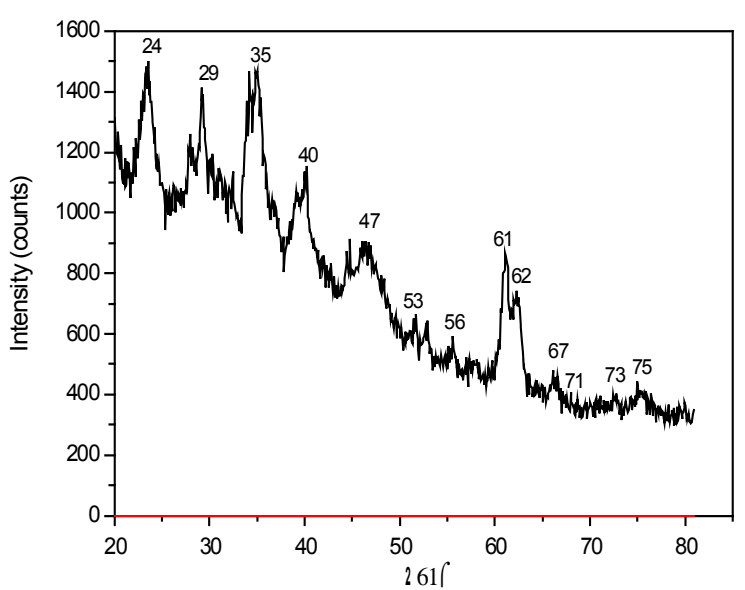

Figure 5: XRD pattern of $L D H$ prepared by urea hydrolysis method; the figures presented at the peaks are $2 \theta$ values of the corresponding peaks

$\mathrm{X}$-ray for $\mathrm{Cu}$ target $(0.1541 \mathrm{~nm}), \beta$ is FWHM (full width at half maxima) in radians, $\theta$ is the Bragg's angle. The average particle size of LDH prepared was calculated to be $59.39 \mathrm{~nm}$ whereby the value of $\beta$ (roughly validated by Gaussian fitting of highest intensity peak at $2 \theta=35^{\circ}$ ) was $0.44^{\circ}$. Similarly, the peak corresponding to $2 \theta$ value at $11.67^{\circ}$ is another characteristic peak of Mg-Al LDHs [35,36] which could not be measured by X-Ray diffractometer (Range: $20^{\circ}$ to $80^{\circ}$ ) used in this experiment.

\section{Conclusion}

Mg-Al layered double hydroxides were successfully prepared by coprecipitation and urea hydrolysis methods using nitrate salts of magnesium and aluminum as starting materials. It has been demonstrated that nano-LDH can be prepared easily in an ordinary chemistry laboratory, even in high schools. FTIR spectra confirm the structure of $\mathrm{Mg}(\mathrm{OH})_{2}$ and $\mathrm{Al}(\mathrm{OH})_{3}$ with $\mathrm{CO}_{3}^{--}$and $\mathrm{NO}_{3}{ }^{-}$ions and $\mathrm{H}_{2} \mathrm{O}$ molecules as interlayer species. These results are further supported by XRD patterns of the materials whereby the peaks appearing at $2 \theta$ values of $35^{\circ}, 71^{\circ}$, and $73^{\circ}$ of corresponding to the Mg-Al hydrotalcites. The average grain diameter of the particles is in the range of 20 to $60 \mathrm{~nm}$. Some impurities such as free $\mathrm{CO}_{3}{ }^{2-}$ ions, and moisture have been detected.

\section{Acknowledgments}

The authors thank Dr. Suresh Kumar Dhungel, Nepal Academy of Science and Technology (NAST), Khumaltar, Lalitpur, Nepal for XRD measurements. Dr. Khaga Raj Sharma and Dr. Sabita Shrestha, both from Central Department of Chemistry, Tribhuvan University, Kathmandu, are further acknowledged for the FTIR measurements. 


\section{References}

1. J. J.Bravo-Suarez, E. A. Paez-Mozo, S. T. Oyama, Review of the synthesis of layered double hydroxides: A thermodynamic approach, Química Nova, 2004, 27(4), 601-604. (DOI: https://doi.org/10.1590/ S0100-40422004000400015).

2. J. Gong, Z. Guan, D. Song, Biosensors based on acetylchlonesterase immobilized onto layered double hydroxides for flow injection/amperometric detection of organophosphate pesticides, Biosensors and Bioelectronics, 2013, 39(1), 320-323. (DOI: https:// doi.org/10.1016/j.bios.2012.07.026).

3. Q. Wang, D. O'Hare, Recent advances in the synthesis and application of layered double hydroxide (LDH) nanosheets, Chemical Reviews, 2012, 112(7), 41244155. (DOI: https://doi.org/10.1021/cr200434v).

4. A. Das, J. J. George, B. Kutlu, A. Leuteritz, D-Y. Wang, S. Rooj, R. Jurk, R. Rajeshbabu, K. W. Stöckelhuber, V. Galiatsatos, G. Heinrich, A novel thermotropic elastomer based on highly-filled LDH-SSB composites, Macromolecular Rapid Communications, 2012, 33, 337-342. (DOI: https:// doi.org/10.1002/marc.201100735).

5. J. Wang, T. Zhang, M. Li, Y. Yang, P. Lu, P. Ning, and Q. Wang, Arsenic removal from water/wastewater using layered double hydroxide derived adsorbents, a critical review, RSC Advances, 2018, 8, 2269422709. (DOI: 10.1039/c8ra03647k)

6. F. Leroux, J-P. Besse, Polymer interleaved layered double hydroxide: A new emerging class of nanocomposites, Chemistry of Materials, 2001, 13(10), 3507-3515. (DOI: https://doi.org/10.1021/ $\mathrm{cm} 0110268)$.

7. F. Li, X. Duan, Applications of layered double hydroxides, Structure and Bonding, SpringerVerlagBerlin, Germany, 2006, 119, 193-223. (DOI: https:// doi.org/10.1007/430_007).

8. U. Costantino, F. Marmottini, M. Noccchetti, R. Vivani, New synthetic routes to hydrotalcite-like compounds, EuropeanJournalofInorganic Chemistry, 1998, 1439-1446. (DOI: https://doi.org/10.1002/ (SICI)1099-0682(199810)1998:10\%3C1439::AID EJIC1439\%3E3.0.CO;2-1).

9. J. Zhang, F. Zhang, L. Ren, D. G. Evans, X. Duan, Synthesis of layered double hydroxide anionic clays intercalated by carboxylated anions, Materials Chemistry and Physics, 2004, 85(1), 207-214. (DOI: https://doi.org/10.1016/j. matchemphys.2004.01.020).

10. D. G. Evans, R.C.T. Slade, Structural aspects of layered double hydroxides, Structure and Bonding, Springer-Verlag Berlin, Germany, 2006, 119, 1-87. (DOI:https://doi.org/10.1007/430_005).
11. L. Cheng, X. Wang, F. Gong, T. Liu, Z. Liu, 2D Nanomaterials for cancer theranostic applications, Advanced Materials, 2020, 32, 1902333. (DOI: 10.1002/adma.201902333).

12. D-Y. Wang, A. Das, A. Leuteritz, R. N. Mahaling, D. Jehnichen, U. Wagenknecht, G. Heinrich, Structural characteristics and flammability of fire retarding EPDM/layered double hydroxide (LDH) nanocomposites, RSC Advances, 2012, 2, 39273933. (DOI: https://doi.org/10.1039/C2RA20189E).

13. C. Mousty, Sensors and biosensors based on clay modified electrodes-new trends, Applied Clay Science, 2004, 27(3-4), 159-177. (DOI: https://doi. org/10.1016/j.clay.2004.06.005).

14. Y. L. Pak, M. B. Ahmad, K. Shameli, Md. Z. W. Yunus, N. A. Ibrahim, N. Zainuddin, Mechanical and morphological properties of poly-3-hydroxybutyrate/ polybutylene adipate-co-terephthalate/layered double hydroxide nanocomposites, Journal of Nanomaterials, 2013, Article ID 621097. (DOI:http:// dx.doi.org/10.1155/2013/621097).

15. X-Y. Yu, T. Luo, Y. Jia, R-X. Xu, C. Gao, Y-X. Zhang, J-H. Liu, X-J. Huang, Three-dimensional hierarchical flower-like Mg-Al-layered double hydroxides: highly efficient adsorbents for $\mathrm{As}(\mathrm{V})$ and Cr(VI), Nanoscale, 2012, 4(11), 3466-3474.

(DOI: https://doi.org/10.1039/C2NR30457K).

16. M. Gong, Y. Li, H. Wang, Y. Liang, J.Z. Wu, J. Zhou, J. Wang, T. Regier, F. Wei, H. Dai, An advanced $\mathrm{Ni}$-Fe layered double hydroxide electrocatalyst for water oxidation, Journal of the American Chemical Society, 2013, 135(23), 8452-8455. (DOI: https://doi. org/10.1021/ja4027715).

17. S. Mohanty, S. K. Nayak, Aromatic-aliphatic poly(butylene adipate-co-terephthalate) bio-nano composites: influence of organic modification on structure and properties, Polymer Composites, 2010, 1194-1204. (DOI: https://doi.org/10.1002/pc.20906).

18. E. Han, D. Shan, H. Xue, S. Cosnier, Hybrid material based on chitosan and layered double hydroxides: characterization and application to the design of amperometric phenol biosensor, Biomacromolecules, 2007, 8(3), 971-975.

19. N. Arora, A. Mehta,A. Mishra. S. Basu, 4-Nitrophenol reduction catalyzed by Au-Ag bimetallic nanoparticles supported on LDH: Homogeneous vs. heterogeneous catalysis, Applied Clay Science, 2018, 1-9. (DOI: https://doi.org/10.1016/j.clay.2017.10.015).

20. Ł. Klapiszewski, J. Tomaszewska, K. Skórczewska and T. Jesionowski, Preparation and characterization of eco-friendly $\operatorname{Mg}(\mathrm{OH})_{2} /$ lignin hybrid material and its use as a functional filler for poly(vinyl chloride), Polymers, 2017, 9, 258 (1-19), (DOI: 10.3390/ polym9070258). 
21 V. A.de Linaje, K. N. Dalby, R. Espinosa, K. M. Dietmann, A. Misol, V. Rives, Adsorption of chlorinated hydrocarbons by $\mathrm{Mg}-\mathrm{Al}$ layered double hydroxides with intercalated surfactant ions: characteristics and sorption studies, Gijón, 5-7 September 2018.

22. L. Wu, D.Yang, G. Zhang, Z. Zhang, S. Zhang, A.Tang, and F. Pan, Fabrication and characterization of $\mathrm{Mg}-\mathrm{M}$ layered double hydroxide films on anodized magnesium alloy AZ31, Applied Surface Science, 2018, 431(15), 177-186. (DOI:https://doi. org/10.1016/j.apsusc.2017.06.244).

23. J. Xie, K. Zhang, J Wu, G. Ren, H. Chen, J. Xu, Bionanocomposite films reinforced with organomodified layered double hydroxides: preparation, morphology and properties, Applied Clay Science, 2016, 126, 72-80. (DOI: https://doi.org/10.1016/j. clay.2016.02.025).

24. N. Kang, D. Wang, B. Kutlu, P. C. Zhao, A. Leuteritz, U. Wagenknecht, G. Heinrich, A new approach to reducing the flammability of layered double hydroxide based polymer composites: preparation and characterization of dye-structure intercalated LDH and its effect on the flammability of PP-g-MA/LDH composites, ACS Applied Materials Interfaces, 2013, 5(18), 8991-8997. (DOI:https:// doi.org/10.1021/am4020555).

25. X. Shan, L. Song, W. Xing, Y. Hu, S. Lo, Effect of nickel-containing layered double hydroxides and cyclophosphazenes compounds on the thermal stability and flame retardancy of poly(lactic acid), Industrial Engineering Chemistry Research, 2012, 51(40), 13037-13045. (DOI: https://doi.org/10.1021/ ie300589p).

26. W. Liao, X-P. Liu, H-Q. Li, P. Yang, Simultaneous removal of phosphate and nitrate on calcined MgAl layered double hydroxides, Polish Journal of Environmental Studies, 2020, 29(1), 187-195. (DOI: https://doi.org/10.15244/pjoes/94991).

27. Z. Navratilova, P. Kula, Clay modified electrodes: present applications and prospects, Electroanalysis, 2003, 15(10), 837-845. (DOI: https://doi.org/10.1002/ elan.200390103).

28. S. P. Mohanty, E. Kougianos, Biosensors: A tutorial review, IEEE Potentials, 2006, 25(2) 35-40. (DOI: https://doi.org/10.1109/MP.2006.1649009).

29. D. Shan, S. Cosnier, C. Mousty, Layered double hydroxides: an attractive material for electrochemical biosensor design; Analytical Chemistry, 2003, 75(15), 3872-3879. (DOI: https://doi.org/10.1021/ ac030030v).

30.D-Y.Wang,A.Leuteritz, B. Kutlu, M.A. derLandwehr, D. Jehnichen, U. Wagenknecht, G. Heinrich, Preparation and investigation of the combustion behavior of polypropelene/ organomodified Mg AlLDH micro-nanocomposites, Journal of Alloys and
Compounds, 2011, 509(8), 3497-3501. (DOI: https:// doi.org/10.1016/j.jallcom.2010.12.138).

31.Z. Yin, J.Wu, Z. Yang, Amperometric sensors based on $\mathrm{Ni} / \mathrm{Al}$ and $\mathrm{Co} / \mathrm{Al}$ layered double hydroxide modified electrode and their application for hydrogen peroxide detection, Biosensors and Bioelectronics, 2011, 26(5), 1970-1974. (DOI: https://doi.org/10.1016/j. bios.2010.08.049).

32. J. V. de Malo, S. Cosnier, C. Mousty, C. Martelet, N. Jaffrezic-Renault, Urea biosensors based on immobilization of urease into two oppositely Charged clays (Laponite and $\mathrm{Zn}-\mathrm{Al}$ layered double hydroxides), Analytical Chemistry, 2002, 74(16), 4037-4043. (DOI: https://doi.org/10.1021/ ac025627+).

33. G. Kampfrath, R. Hintsche, Plasma polymerized thin films for enzyme immobilization in biosensors, Analytical Letters, 1989, 22(11 \& 12), 2423-2431. (DOI: https://doi.org/10.1080/00032718908052364).

34. J. He, M. Wei, B. Li, Y. Kang, D. G. Evans, X, Duan, Preparation of layered double hydroxides, SpringerVerlag Berlin Heidelberg, 2005, 119, 89-119. (DOI: https://doi.org/10.1007/430_006).

35. G. Hu, N. Wang, D. O'Hare, J. Davis, Synthesis of magnesium aluminum layered double hydroxides in reverse microemulsions, Journal of Materials Chemistry, 2007, 17(21), 2257-2266. (DOI: https:// doi.org/10.1039/B700305F).

36. X-Y. Yu, T. Luo, Y. Jia, R-X. Xu, C. Gao, Y-X. Zhang, J-H. Liu, X-J. Huang, Three-dimensional hierarchical flower-like Mg-Al-layered double hydroxides: highly efficient adsorbents for $\mathrm{As}(\mathrm{V})$ and Cr(VI), Nanoscale, 2012, 4(11), 3466-3474. (DOI: https://doi.org/10.1039/C2NR30457K).

37. F. R. Costa, A. Leuteritz, U. Wagenknecht, D. Jehnichen, L. Häußler, G. Heinrich, Intercalation of $\mathrm{Mg}$-Al layered double hydroxide by anionic surfactants: Preparation and characterization, Applied Clay Science, 2008, 38, 153-164. (http://dx.doi. org/10.1016/j.clay.2007.03.006).

38. H. Ji, W. Wu, F. Li, X. Yu, J. Fu, L.Jia, Enhanced adsorption of bromate from aqueous solutions on ordered mesoporous $\mathrm{Mg}-\mathrm{Al}$ layered double hydroxides (LDHs), Journal of Hazardous Materials, 2017, 334, 212-222. (https://doi.org/10.1016/j. jhazmat.2017.04.014).

39. V. Rives, M. A. Ulibarri, Layered double hydroxides (LDH) intercalated with metal coordination compounds and oxometalates, Coordination Chemistry Reviews, 1999, 181(1), 61-120. (https:// doi.org/10.1016/S0010-8545(98)00216-1). 